Бұл CC BY-NC-ND лицензиясы бойынша қол жетімді мақала (https://creativecommons.org/licenses/by-nc-nd/3.0/) «Ғылымның өзекті мәселелері» - Халықаралық практикалық интернет- конференция материалдары

Басылым II, Қараша 2019

ISBN 978-601-323-144-0

https://doi.org/10.31643/2019.028

Ергалиева Меруерт

2-курс магистранты, Абай ат. КазҰПУ

E-mail: Mikaa-95@mail.ru

\title{
Білім беру ортасының балалардың мектепке даярлығын қалыптастырудағы алатын орны
}

\begin{abstract}
Абстракт: Бұл мақалада мектепке дейінгі балалардың мектепке даярлығын қалыптастыруда білім беру ортасының рөлі туралы айтылады. Балалардың мектепке дайындығының алғышарттарына тоқтала отырып, білім беру ортасы, мектеп жасына дейінгі балалар, мектепке даярлық, мектепке даярлықты қалыптастыру түсініктеріне кеңінен тоқталып, баяндалады.

Кілт сөздер: білім беру ортасы, мектепке даярлық, жеке бастың дайындығы, интеллектуалдық дайындық, әлеуметтік дайындық, мектепке дейінгі жас, балабақша.
\end{abstract}

Қазіргі заманғы білім беру дамудың жаңа кезеңінде - оны жаңғырту жүріп жатыр. Бұған қоғамда болып жатқан әлеуметтік және экономикалық өзгерістер ықпал етеді. Осылайша, қазіргі қоғам 6 жастан 60 жасқа дейінгі адамның, ересек адамның немесе баланың жаңа түрін құрды, өйткені бұрын болған ересектер мен балалар арасындағы айқын бөлініс біртіндеп жоғалады. Балалық шақтың жоғалуын біздің елде де көруге болады, "балаларды белгіленген жағдайда өсіру" процесін байқауға болады. Бұл ретте балалар өмірінің жағдайы, мазмұны, қоршаған ортамен күнделікті қарым-қатынас ересектер үшін қатаң жоспарланады. Біздің балаларымыз бүгін олардың табиғатын тікелей дамыту мүмкіндігінен айрылды, олар қазіргі қоғамның өмір сүру жағдайларымен шектелді. Олардың әлемді игеру тәсілі тікелей (өзін-өзі тану арқылы) теледидарға, әдебиеттерге, компьютерге және т. б. айналады. Балалар іздеу, бақылау, тәжірибе және т.б. қажеттіліктерді сезінбейді, өйткені олар теледидардан, ересектерден және т. б. дайын ақпаратты ала алады. Сонымен қатар, ересектер балалар мінез-құлқының сыртқы және ішкі дүниелердің бірлігі, баланың қазіргі кездегі өмір сүруі, өз идеялары мен қажеттіліктерін дереу іске асыру қажеттілігі, құндылықтар мен сезімдер туралы өз түсінігін қабылдамайды. Эмоциялық тұрақты базистің жоғалуына қазіргі заманғы балалардың өмір сүру жағдайлары ықпал етеді: көшелерде ойнауға, табиғаттан айырылуға, көше қозғалысының қарқындылығы және өмірге қауіп төнуі (қылмыстың өсуі және т.б.), өз балаларымен табиғи қарымқатынас жасауға ата-аналардың уақыт жетіспеуі, олардың жас отбасыларда тәрбиеленуі және т. б.

Кеңістіктік-пәндік орта - ересектердің қызметінің өнімі. Көбінесе оның құрылымдық және функционалдық параметрлері балалар ағзасының психикалық және физикалық дамуының ерекшеліктерін, белсенді тұрақты қозғалыстардың, іздеудің, қиялдың, эксперименттің қажеттілігін ескермейді.

Білім беру мекемелерінде пәндік-кеңістіктік ортаны ұйымдастыру мәселесі соңғы уақытта педагогтар мен психологтар арасында талқылаудың өзекті мәселелерінің бірі болып табылады, 
өйткені бұл проблеманы шешу қазіргі қоғамның әлеуметтік тапсырысымен қайта қарауды және келісуді талап етеді. Қазіргі заманғы мектепке дейінгі мекемелердің пәндік-кеңістіктік ортасы, қайта құру кезеңінен бері іс жүзінде өзгерген жоқ. Әрбір мектепке дейінгі мекеменің өз мақсаттары мен міндеттері бар, сәйкесінше әрқайсысында мектепке дейінгі балаларды тәрбиелеу мен білім беру үшін өз жағдайларын қалыптастыру қажет.

Мектепке дейінгі мекеменің негізгі мақсаттары - мектепке дейінгі және бастауыш жалпы білім беру арасындағы сабақтастықты, тәрбиеленушілер мен білім алушылардың денсаулығын сақтау мен нығайту, дене және психикалық дамуы үшін оңтайлы жағдайларды қамтамасыз ету жолымен білім беру процесін жүзеге асыру. Мектепке дейінгі мекеме қандай типке жатпаса да, оның негізгі міндеттерінің бірі мектепке дейінгі балалардың мектепте оқуға дайындығын қалыптастыру болып қалуда, ол өз кезегінде белгілі бір педагогикалық жағдайларда өтеді [1].

1988 жылы Германияда жаңа экопсихологиялық және экопедагогикалық зерттеулерді есепке ала отырып, балабақша ғимаратының ең үздік архитектуралық шешіміне конкурс жарияланды.

Барлық ұсынылған жұмыстарды талдау нәтижесінде бірнеше жобалар мақұлданды, тек қана балалардың өмірін қорғайтын, сақтайтын, сонымен қатар дамытатын, серпінді орта құруға бағытталған жобалар мақұлданды. Тек 10 жоба ғана әлеуметтік мәселелер министрлігінің арнайы ұсыныстарын есепке алды және балабақшаларды жаппай еуропалық үлгіде жабдықтау тұжырымдамасының негізі болып табылды.

Ең алдымен, балабақшалар ғимараттарының жобалары бірден сол немесе басқа балабақшаға баратын балалар санына есептелуі тиіс. Балалардың белгілі бір санына қарай ішкі және сыртқы үйжайлардың саны мен ауданы, олардың мақсаты мен жабдықталуы есептелуі тиіс. Біздің елімізде қазіргі заманғы талаптарға сай келмейтін балабақшалардың ескі ғимараттары әлі күнге дейін пайдаланылуда. Ғимараттар аз қалды, кейде сабаққа арналмаған, ал топтағы балалар саны азаймайды. Ғимараттардың ішкі және сыртқы безендірілуін балалар көзіне тартымды деп айту қиын.

Балабақша кеңістігінің құрылымы мен көп функциялылығының қазіргі мәселесі мектепке дейінгі балалардың әлеуметтік және физикалық дайындығын қалыптастыруда үлкен рөл атқарады. Осыған байланысты топтық бөлменің кеңістігін құрылымдау оны акустикалық және оптикалық жағынан бір-бірінен бөлінген аймақтар жиынтығына саралауды білдіреді. Бұл ретте әртүрлі бөлгіш элементтер (жылжымалы қабырғалар, жиһаз, өсімдіктер, жалюздер, торлар, шатырлар және т.б.) пайдаланылуы мүмкін. Бөлмеде әр түрлі мақсатты бұрыштармен қатар, оған барлық балалар еркін қол жеткізе алатын көпфункционалды сипаттағы аймақ болуы тиіс. Көптеген тәрбиешілер бұл бөлмелерді жазалау орны ретінде жиі қолданады немесе балаларға оларда болуға тыйым салады, сол арқылы олардың кеңістікте қозғалуын және достарымен қарым-қатынас мүмкіндігін шектейді, оны "балалар көз алдында болуы тиіс" деп түсіндіреді. Бұл ретте психологиялық жеңілдету мақсатында балалардың демалысы мен бір-бірінен оқшаулануын ұйымдастырудың айқын проблемасы шешілмейді. Балалар бір-бірінен тез шаршайды, нәтижесінде төбелес, талқылаулар пайда болады. Тәрбиешілер баланың мінез-құлқы мен тәрбиесіндегі агрессивтілік себебін неде екенін іздейді, ал іс жүзінде барлығы балалардың демалуы үшін тыныш орын болмауымен түсіндіріледі. Тыныш ойындар немесе балалардың шағын тобының қарым-қатынасына арналған жеке бөлменің болуы қазіргі заманғы балаларға қажет. Кейбір сабақтарды өткізу тек жақында ғана топтық бөлмеден тыс жүзеге асырыла бастады, бұл өз кезегінде жағдайды ауыстыруға және психологиялық жүктемені түсіруге ықпал етеді. Алайда бүгінгі күні әр түрлі сабақтар мен кабинеттерді жабдықтау үшін кеңістікті ұйымдастыру мәселесі әлі де қалып отыр. Кабинеттің кеңістігі балалардың санына сәйкес келмейді, кабинеттің жабдықталуы сабақты ұйымдастырудың әртүрлі нысандарын жүргізу үшін жеткіліксіз.

Германияда Министрліктің ұсынымдары бойынша, мысалы, бөлме ауданы 6,8 шаршы метр, бір балаға есептелуі тиіс. Барлық бөлме ойын, сабақ, қарым-қатынас, тәжірибе, бақылау және т. б. үшін жеке арналған көп деңгейлі және көпфункционалды аймақтарға бөлінуі тиіс. Аймақтарға бөлу кезінде тыныш және жылжымалы қызмет түрлеріне арналған ойын бұрыштарын бөлген жөн. Ең бастысы, балалар бірге серуендеулері, бір-бірін тыңдай алулары, бір-бірін сезе алулары, өз ісітерімен айналысып, жанжалдарды өзара шешіп, кітап оқып, жоспарларды талқылай білулері керек.

Құрылымдық безендіруге топтық бөлменің тік жазықтығы да жатады, сондықтан оларда барынша қозғалу белсенділігін қамтамасыз ету үшін әртүрлі құрылымдарды, турниктерді құрастыру, әртүрлі деңгейлі жабдықты орналастыру қажет. Жасырын бұрыштарды, өрмелеу үшін қараңғы туннельдерді, үңгірлерді, биік алаңдарды құру тек моторлы функцияларды дамытып қана қоймай, балалардың қиялын дамытады, шытырман оқиға атмосферасын жасайды.

Мектепке дейінгі балалардың физикалық және психикалық денсаулығын сақтау үшін топтық бөлмелерді безендірудің жарықтандырылуы мен түс шешімі ерекше маңызға ие. Жарықтандыру 
сипаты, оның табиғи, вариативтілігі, қарқындылығы, кеңістікті және ондағы заттарды қабылдау үшін маңызды. Осыған байланысты жарықтандыру құралдарының орналасуы мен сапасы маңызды болып табылады. Төбеден өтетін бүгінгі танда қолданылатын дифференциалды емес жарықтандыру жеткіліксіз. Оны пішін бойынша әртүрлі шамдармен толықтыру оңай қозғалысқа итермелейді және балалардың иелігінде болады. Бөлменің үлкен терезелер арқылы табиғи жарықтандырылуы ерекше маңызға ие. Германияда түрлі-түсті терезелер мен түрлі-түсті жарықтарды пайдалану бойынша эксперименттер орын алды, және ғалымдар түрлі-түсті әлем бала үшін ерекше тартымдылық пен қайталанбастыққа ие болатынын атап өтті. Ғимаратты безендірудің заманауи шетелдік жобалары психологтардың табиғи түстердің қараңғы түстерін пайдалану ұсынымдарын ұстана бастады: қызыл, көк, жасыл, қоңыр, сары, қызғылт сары түстері шамамен сол гамма жарықтандырумен бірге және адамдарға оң әсер етеді.

Жарықты дұрыс пайдалану - бұл жоба авторларының пікірінше, мектепке дейінгі балалардың психологиялық және зияткерлік дайындығының дұрыс дамуына ықпал етеді. Балалардың түс пен жарыққа сезімталдығы зейін, қиял, концентрация, шығармашылық, реңктер мен формаларды қабылдау, заттарды бақылау, ажырату, салыстыру, осыған ұқсас жасау және т. б. Балабақшаның экологиялық тұжырымдамасының маңызды құрамдас бөлігі көшедегі алаңды жабдықтау болып табылады. Балалар әлемінің бір бөлігі бола отырып, кеңістік стандартқа сәйкес құрылуы тиіс [2].

Мектепке дейінгі тәрбие мен оқытудың мемлекеттік жалпыға міндетті стандарты

1. Жалпы ережелер 1. Осы мектепке дейінгі тәрбие мен оқытудың мемлекеттік жалпыға міндетті стандарты (бұдан әрі - стандарт) «Білім туралы» Қазақстан Республикасының 2007 жылғы 27 шілдедегі Заңына сәйкес әзірленді. Стандартта «Білім туралы» Қазақстан Республикасының Заңына сәйкес терминдер пайдаланылады.

Мектепке дейінгі білім беру - бұл үш пен жеті жас аралығындағы баланы оқыту, дамыту, тәрбиелеу, қарау және күту. Мектепке дейінгі оқыту мен тәрбиелеу мақсаты осы жас кезеңінде тұлғаның қалыптасуы үшін қажетті алғашқы білім, білік және дағдыларды қалыптастыру болып табылады. Жеті жасқа дейінгі балалар шындап үйрену үшін тым кішкентай болып көрінеді, алайда жете дайындалуынсыз балаға кейіннен мектепте оқу қиын болады.

Білім балаларға ойын түрінде ұсынылады, мектеп жасына дейінгі баланың ойын арқылы сабаққа көңілін аудару оңай. Ойын түрінде қажетті дағдылар қалыптап, олар ойын барысында пысықталады. Бұл ретте оқытушылар мектепте оқығанда керек болатын дағдыларды қалыптастыруға ерекше назар аударады.

Оқыту мен тәрбиенің екінші бөлігі - мектепке даярлау - 4-5 жастан басталады, бұл кезде баланың бастауыш оқу, жазу, есептеу дағдылары қалыптасады, тіл арқылы қатынасу тәжірибесі дамиды. Бұл мектепке дейінгі мекеме түрі 6-7 жастағы балалардың негізгі бөлігін қамтиды.

Балабақшаларды балалар жастық топтарға бөлінеді: ерте жастағы топ - 1 жастан 2 жасқа дейін; бірінші кіші топ - 2 жастан 3 жасқа дейін; екінші кіші топ - 3 жастан 4 жасқа дейін; ортанғы - 4 жастан 5 жасқа дейін; мектепке дейінгі топтар: ересектер тобы -5 жастан 6 жасқа дейінгі және мектепалды даярлық тобы - 6 жастан 7 жасқа дейінгі балалар.

Мектепке дейінгі тәрбие мен оқытудың мазмұны әртүрлі іс-әрекеттерді ұйымдастыру арқылы кіріктіру жолдарымен іске асырылатын: "Денсаулық", "Коммуникация", "Таным", "Шығармашылық", "Әлеуметтік орта" бес білім беру саласына негізделген.

Ұйымдастырылған оқу қызметінің ұзақтығы:

$>$ Ерте жастағы балалар үшін - 7-15 минут;

> Мектепке дейінгі орта жастағыбалалар үшін - 15-20 минут;

> Мектепке дейінгі естияр жастағы балалар үшін - 25-30 минутты құрайды [3].

Мемлекеттердің әлеуметтік және экономикалық мүмкіндіктеріне, халықтардың дәстүрлері мен әлеуметтік менталитетіне, елдердің географиялық орналасуына қарамастан, балаларды мектепке жанжақты даярлау қажеттілігі жалпыға бірдей, айқын міндет болып табылады.

Бастауыш білім беру (мектепке дейінгі бастауыш білім беру) әлеуметтік, экономикалық және әлеуметтік-педагогикалық сипаттағы шешім деп әлемдік қоғамдастық мойындады [4].

Ғылымда "орта" ұғымының айқын анықтамасы жоқ. "Орта" сөзі "орта" дегенді білдіреді. Қазіргі орыс тілінде "ортасында", яғни қарастырылып отырған объектілер арасында аралық орын алады және олардың арасындағы делдал болып табылады. Және ол қандай құжаттың негізіне 
сүйенеді. Ю. Шведова " орта "ұғымына келесі мағынаны береді:" өмір сүруге, бірдеңені тудыруға қолайлы жағдай "[5].

Қазіргі заманғы философия ортаны жеке дамудың жалғыз факторы емес, шешуші фактор ретінде қарастырады.

Адам үшін орта - оның психологиялық, рухани, әлеуметтік, мәдени ортасы. "Орта" ұғымының заманауи түсіндірмелері контекстпен анықталады. Д. Ж. Маркович, П. А. Сорокин [6] және т.б. оны әлеуметтік аспектіде қарастырады: "кейбір ортада болатын өз ара байланысты жағдайлар мен әсерлердің жиынтығы"; "индивидтердің құндылықты-бағытталған қатынастарының әлеуметтік Көп өлшемді кеңістігі, белгілі бір иерархияланған, онда индивидтердің көлденең және тік бағыттарда әлеуметтік орын ауыстыру мүмкіндігі бар.

Білім беру адамның дамуы өтетін ортаға байланысты, ол көбінесе оның дүниетанымының жеке контекстін анықтайды. Бүгінгі білім алатын балалар 10 жыл бұрынғы өз құрдастарынан өзгеше. Олар ақпараттандырылған, ашық, көпшіл, серпінді өзгеретін білім беру ортасын талап етеді. Мысалы, олар үшін визуалды қабылдау, әлем туралы бейнелі түсініктер айтарлықтай үлкен рөл атқара бастады, бұл нақты-көрнекі және теориялық танымның танымдық және оқу іс-әрекетінде арақатынас мәселесі күрделенді. Білім беру жүйесінде тұлғаны қалыптастырушы орта құру - білім берудің гуманистік тұжырымдамасын, оның мақсаттары мен міндеттерін педагогикалық процестің барлық кезеңдерінде жүзеге асыруға ықпал ету, деп санайды А. А. Макареня [7].

Ерте жаста пайда болған адамдармен қарым-қатынас жасау қажеттілігін қанағаттандыра отырып, алты-жеті жастағы бала іскерлік (көмек немесе бірлескен қызмет және т.б. туралы өтініш) және танымдық және жеке тұлға болуы мүмкін, құжаттан тыс қарым-қатынасты пайдаланады. Мұндай қарым-қатынас кезінде бала қоршаған ортаның құбылыстары мен заттары танып, нақтыланады, қарым-қатынастың осы түрінің негізгі себебі ересектерге жаңа ақпарат алу үшін ұмтылу болады.

Мектеп жасына дейінгі баланың қабілеттері дәл, сезімтал қабылдауға, күрделі жағдайларда жол таңдауға епті, сөз байламы пайымды, бақылағыш және тапқыр келеді. 6 жасқа жақындағанда арнайы, мысалы, музыкалық, көркемөнөрлік қабілеттері дами бастайды.

Мектеп алды баласы көп нәрсе біледі және көп нәрсені орындай алады. Бұл кезеңдегі жетілген ақыл-ес дамудың қортындысы - көрнекі-бейнелі ойлаудың ең жоғары түрі. Баланың ақыл дамуында математикалық ұғымдар маңызды рөл атқарады. Кейінгі он жылдықтарда әлемдік педагогика 6 жасар балаларды оқыту мәселелеріне орайлас логикалық, математикалық, жалпы абстракт ұғымдарды қалыптастырудың көптеген қырларын түбегейлі зерттеді. Осының арқасында мұндай абстракциялар пайда ету үшін бала ақылы әлі жетіспегені дәлелденді. Дегенмен, орынды әдістерді қолданып, оқытатын болсақ, бала білім игеруде көңіл толарлықтай табыстарды иеленуі мүмкін. Ақыл дамуы желісінде түсінім «кедергілері» ұшырасады. Бұл құбылыстың мәнін ашуда швед психологы Ж. Пиаже көп еңбектенген. Балалар ойын барысында ешқандай оқымай-ақ заттардың формасы, көлемі, саны жөніндегі түсініктерді жеңіл игеріп алады. Бірақ, арнайы педагогикалық басшылық болмай, қатынастарды түсіну «кедергілерінен» балалардың аттап өтуі қиын. Мысалы, мектепке дейінгі бала қай жерде көлемдік, ал қай жерде сандық артықшылық барын түсіне алмай дал болады. «Бір келі мақта ауыр ма, бір келі темір ауыр ма?» деген сұраққа бала ойлануға ақылы жетпегендіктен - бір келі темір ауыр дей салады. Бұл қарапайым мысал ойлаудың принциптік мүмкіндіктерін ашып береді. Мектеп жасына дейінгі баланы өте қиын және күрделі заттарға (мысалы, интеграл есептеулерге) үйретуге болады, бірақ, одан түсер пайда жоқтың қасы. Халықтық педагогика, әлбетте «Пиаже кедергілерін» білген, сондықтан да, бала тәрбиесіне даналықпен келесі тұжырымды қосқан: «Жас күнінде - жаттасын, есейгесін - түсінер».

Г.Б. Бейсенбекова, Р.А. Молдабаева мен С.М. Нұрғалиеваның «Жас ерекшелік психологиясы» атты еңбектерінде [8], мектептеге окуға дайындық:

- жеке бас;

- интеллектуалдық;

- әлеуметтік, болып көрсетілген.

Жеке бастың дайындығы - белгілі бір құқық және міндеттері жүйесі бар, мектеп оқушысының жағдайын жаңа әлеуметтік позицияларға баланың даярлығын қалыптастыру. Бұл жеке бастың дайындық баланың мектепке, оқуға, мұғалімге, өз-өзіне деген қатынасын айқындайды. Жеке бастың даындық дамудың мотивационды және эмоционалды өрісіның даму деңгеімен анықталады.

Интеллектуалдық дайындығы - баладан нақты білім қорын, ой-өрісін талап етеді. Бала жоспарлы бөлшектелінген қабылдауды, аналитикалық ойлауды, логикалық есте сақтауды, сөйлеудің ырықтылығын, белгілерді қолдану барысында танып білуге қабілеттілігі болуы тиіс. 
Әлеуметтік дайындығы - баланың қарым-қатынасқа деген қажетсінуінің дамуын және де балалар тобының ережелеріне және қызығушылықтарына бағынуды меңгереді. Олардың басқалармен, мұғалімдермен қарым-қатынас орнатуына ықпалы бар сапалар жатады.

Мектепке дейінгі кезеңдегі бала дамуының ерекшеліктері

\begin{tabular}{|c|c|c|}
\hline $\begin{array}{c}4 \text { жас. } \\
\text { Екінші сәбилік кезең }\end{array}$ & & \\
\hline 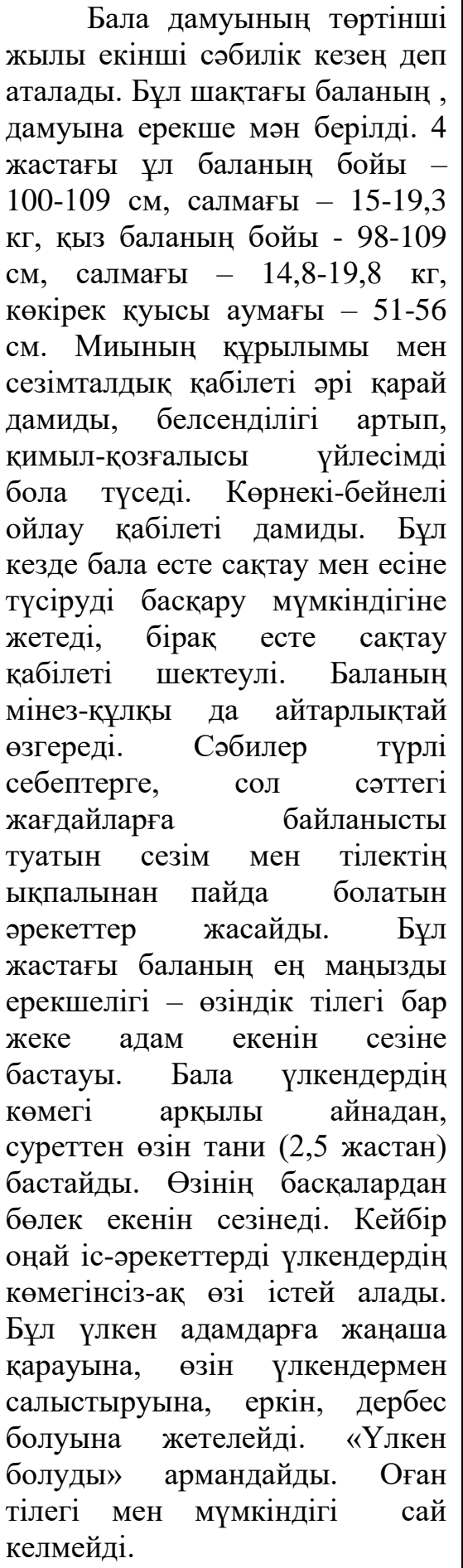 & 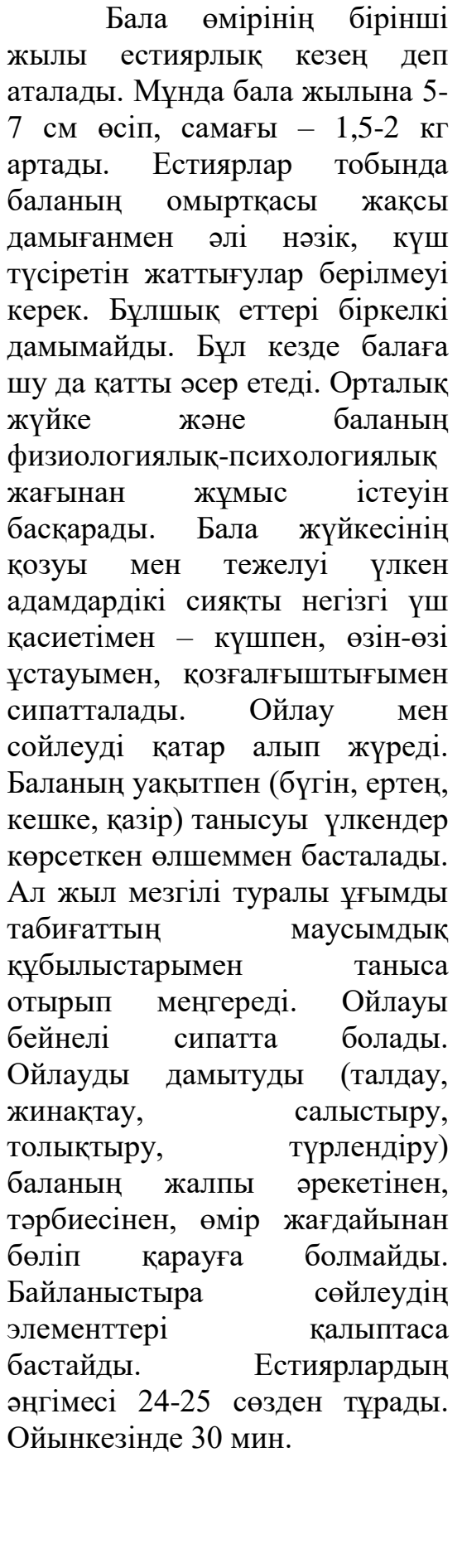 & 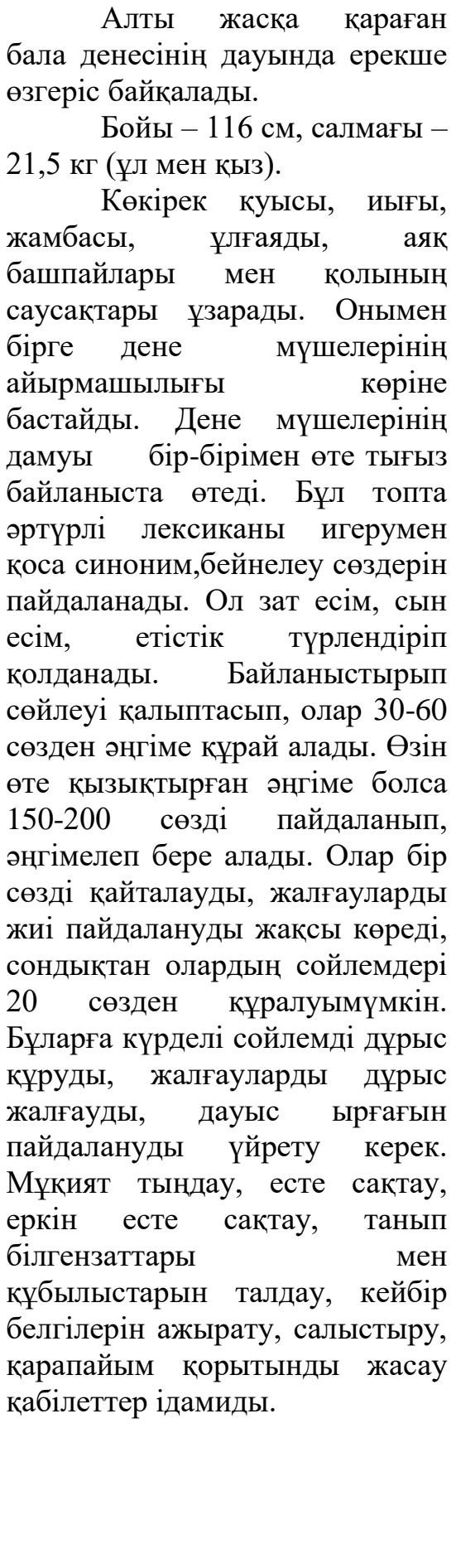 \\
\hline
\end{tabular}

Бүгінгі таңда мектепке дейінгі тәрбие жүйесі әр елде алуан түрлі даму деңгейінде болып отыр. Оның басты себептері: мектепке дейінгі тәрбиенің мемлекет пен қоғамның қатынасына, қоғамдағы әлеуметтік-экономикалық жағдайларға, әр елдің салт-дәстүрі мен мәдениетіне, аймақтық 
ерекшеліктеріне де байланысты болмақ. Педагогика көп жағдайда сол елдегі қолданыстағы заңнамаға немесе жетекші идеологияға тәуелді дамиды. Мектепке дейінгі ұйымдар елдің не әлеуметтік қызмет көрсету, не денсаулық сақтау ұйымдарына немесе білім беру жүйесіне қарайтын болады. Осыған байланысты мектепке дейінгі ұйымдардың жұмыс бағыттары, педагогикалық дайындық деңгейлері өзгереді. Мектепке дейінгі ұйымдар әлеуметтік қамсыздандыру министрлігіне қарайтын елдерде (Австрия, Англия) ата-аналар қалауымен балаға күндізгі қамқорлық түрінде ұйымдастырылуы басым болса, Білім министрлігіне қарайтын елдерде (Ирландия, Қытай) ерте жастан бастап оқыту процесі басым. Ал кейбір елдерде мектепке дейінгі білім беру енді-енді министрліктер қарамағына еніп отыр (Түркия, Жапония).

Тәрбие сапасы педагогтардың кәсіби біліктілігіне байланысты. Көптеген дамыған елдерде тәрбиешілердің дайындығы жеткілікті жоғары деңгейде (Германия, Франция, Англия, АҚШ, т.б.) болып, олар әртүрлі бағыттарда (музыкалық, дене тәрбиесі, ақыл-ой тәрбиесі, эстетикалық) жұмыс жүргізе алады және балалардың дамуының өсуін бақылай біледі [9].

"Білім беру ортасы" және "білім беру кеңістігі" ұғымдарына теориялық талдау жасай отырып, олардың мектепалды білім беру ұйымындағы мүмкіндіктеріне негізделгенін көруге болады. Мектепке дейінгі ұйымда баланың тұлғасына кеңістіктік-орта әсер ету мүмкіндіктері жеткіліксіз зерттелмеген және педагогикалық практикада аз пайдаланылады.

Тұтастай алғанда, баланың табиғатына сай еуропалық елдердің мектепке дейінгі мекемелерінде сақтаушы және дамытушы ортаны құру тәжірибесін талдау оның шешудегі айтарлықтай ілгерілеушілігін куәландырады. Мектепке дейінгі мекемелердегі балалардың пәндік-кеңістіктік өмір сүру әлемі проблемалары қазіргі қоғамның мектепке дейінгі балаларды тәрбиелеуде және дамытуда маңыздылығын көрсетіп отыр.

Біздің елімізде мектепке дейінгі ұйымда дамытушы пәндік-кеңістіктік ортаны құруда түрлі эксперименттер жүргізіліп жатқанын, осы салада жобалар әзірленіп, ғылыми зерттеулер жүргізіліп жатқанын жоққа шығаруға болмайды, алайда еуропалық елдердің тәжірибесі еліміздегі мәселелерді шешуде құнды болар еді.

\title{
Ergalieva Meruert
}

$2^{\text {nd }}$ year master student, Abai University

E-mail: Mikaa-95@mail.ru

\section{Role of educational environment in forming ready for children for school}

\begin{abstract}
This article discusses the role of the educational environment in shaping the readiness of preschool children. Considering the basic prerequisites for the level of readiness of children for school, the concepts are widely described and explained: educational environment, preschool age, readiness for school, the formation of children's readiness for school, preparation for school.

Keywords: educational environment, school readiness, individual readiness, intellectual readiness, social readiness, preschool age Kindergarten.
\end{abstract}

Мақалаға сілтеме: Ергалиева М. (2019), Білім беру ортасының балалардың мектепке даярлығын қалыптастырудағы алатын орны. «Ғылымның өзекті мәселелері» Халықаралық практикалық интернет- конференция материалдары / Materials of International Practical Internet Conference "Challenges of Science". ISBN 978-601-323144-0. Басылым II, 2019. Бет: 141-147. https://doi.org/10.31643/2019.028 


\section{Пайдаланылған әдебиеттер тізімі}

[1] Нравственное воспитание в детском саду / Под ред. В.Г. Нечаевой, Т.А. Марковой. М., 1984.12106 организации предшкольного образования // Справочник руководителя дошкольного учреждения. М., 2005. - № 8 .

[2] Прохорова С. Ю. Предшкольное образование и система работы с родителями. М.: Аркти, 2008.

[3] http://egov.kz/cms/kk/articles/preschool

[4] Тыныштык Калдыбаева, Дошкольное образование. Социология и междисциплинарные аспекты, «Издательство Елтаным» Алматы, 2013

[5] Крупская Н.К. Избранные педагогические произведения. М.-Л., 1948

[6] Юб.Менджерицкая Д.В. Воспитателю о детской игре. М., 1982.

[7] ЮЗ.Макареня А.А. Трехмерное пространство проживания сообщества и малая образовательная среда воспитания индивида // Избранные труды. Т.ІІІ. Тюмень: ТОГИРРО, 2000. б.193-198.

[8] Бейсенбекова Г.Б., Молдабаева Р.А., Нұрғалиева С.М. Жас ерекшелік психологиясы, Қарағанды, 2012 